\title{
A remarkable record of the genus Pseudolucia from Bolivia (Lepidoptera: Lycaenidae)
}

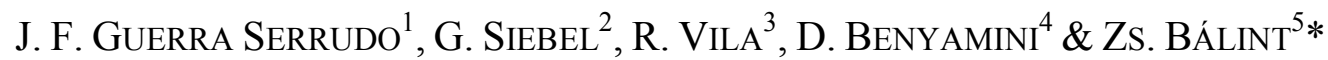 \\ ${ }^{1}$ Juan Fernando Guerra Serrudo, Investigador Asociado, Instituto de Ecologia C.P. 10077 La Paz. Obrajes \\ Calle 4 no' 320 Avenida H. Ormachea, La Paz, Bolivia.Email:ferguerrafideo@yahoo.com \\ ${ }^{2}$ Gottfried Siebel, 6 de Agosto, 2636,25/8 La Paz.Email: siebelg@yahoo.de \\ ${ }^{3}$ Roger Vila, Institut de Biologia Evolutiva (CSIC-Universitat Pompeu Fabra), Passeig Maritim de la \\ Barceloneta, 37,08003,Barcelona, Spain.Email: roger.vila@csic.es \\ ${ }^{4}$ Dubi Benyamini, 4D MicroRobotics, 91 Levona str. Bet Arye, Israel 7194700.Email: dubi_ben@netvision.net.il \\ ${ }^{5}$ Zsolt Bálint, Department of Zoology, Hungarian Natural History Museum, Budapest VIII, Baross utca 13, H- \\ 1088, Hungary. Email: balint.zsolt@nhmus.hu, *corresponding author.
}

\begin{abstract}
The occurrence of a taxon morphologically close to Pseudolucia jujuyensis Bálint, Eisele \& Johnson, 2000 is recorded in dry habitats of Torotoro Dinosaurs National Park, Potosí, Bolivia. This record remarkably extends the range of Pseudolucia by almost $800 \mathrm{~km}$ northwards in austral South America. Five specimens were available for examinations, hence wing-pattern, genitalia and mitochondrial DNA were analysed. However, the taxonomy of the specimens could not be satisfactorily resolved in relation to $P$. jujuyensis, for which only the holotype exists. The females use Cuscuta for ovipositing, what is supposedly the larval host - a remarkable character of the chilensis species group of Pseudolucia, which includes P. jujuyensis. On the basis of molecular markers it was revealed that the Torotoro population is the sister to the rest of the chilensis species group, which together are the clade sister to the rest of the genus.
\end{abstract}

Keywords. Andes, Argentina, Bolivia, butterfly, distribution, phylogeny, prepuna biome, Pseudolucia, systematics.

\section{INTRODUCTION}

$\mathrm{T}$ he genus Pseudolucia represents the main South American endemic radiation of the lycaenid tribe Polyommatinae. When the genus was established by Vladimir Nabokov on the basis of two species, its distribution was believed to be restricted to a limited area in central Chile (Nabokov 1945). Since then, mainly based on the efforts of one of us (Benyamini), who led numerous expeditions to the austral South America, representatives of the genus have been recorded from the department Jujuy in the north of Argentina to Santa Cruz in the south, and in Chile from the Antofagasta (North of Atacama) region to the Magallanes (adjacent Tierra Del Fuego) region (Benyamini 2013, Bálint \& Benyamini 2014).
After processing the material collected by these expeditions, the species in the genus have been raised to 55 , more than one order of magnitude (Benyamini \& Bálint 2015). Many formerly or newly described species have been sampled several times, but the species Pseudolucia jujuyensis Bálint, Eisele \& Johnson, 2000, the most northerly member of the genus, remains an enigma. It was described on the basis of a single male specimen collected in 1977 in Coraya, Humahuaca, department of Jujuy, Argentina, but efforts aiming at its rediscovery turned to be unsuccessful (Benyamini \& Bálint 2015). It is suspected that the singleton holotype was blown up or was a specimen performing hill-toping because there is no potential larval host plant in the area (tens of kilometres) around the biotope. 
A recent expedition led by the senior author in Central Bolivia in order to search Strymon heodes (see Bálint \& Benyamini 2017), resulted in the discovery of a Pseudolucia species in the region. This record is remarkable as it extends the range of the genus by almost $800 \mathrm{~km}$ northwards in austral South America. This is the single Pseudolucia species known to occur in Bolivia.

The aim of the present paper is to report and to document the discovery, and to discuss the identity of the specimens using morphological and molecular traits. We also annotate the biology of the closely related Pseudolucia species and stress the importance of the new record from a zoogeographic point of view.

\section{MATERIALS AND METHODS}

Four males and one female, all from Bolivia, Potosí, Torotoro Dinosaurs National Park, 2700$2850 \mathrm{~m}$ have been examined. Two males collected 30.III.2016 by G. Siebel (male: Dubi Benyamini's collection number 0300, RVcoll16M146; another male: deposited in the Hungarian Natural History Museum, RVcoll16M147); two males and one female collected 13.XII.2016 by J. F. G. Serrudo (all in Dubi Benyamini's collection, male numbers 0302-0303, RVcoll16M148-16M149, female: 0301, RVcoll16M150) (Table 1).

Because of the uncertainty of the relation of the discovered population to the holotype of Pseudolucia jujuyensis, we apply the informal name "torotorensis" for the Bolivian population. In this way, we want to stress the uniqueness of the population discovered, but it cannot be considered as a nomenclatorial or a taxonomic action. Therefore the name "tortotorensis" is not available for the zoological nomenclature.

Adult behaviour and habitat were recorded in situ using digital cameras. Samples of adult butterflies, nectar-sources and supposed larval hosts were hand-collected by local scientists and desiccated. Subsequently they were transferred to Benyamini's laboratory and were databased there. Conservation, curation, dissection and setting of the samples were done by traditional methods (Winter 2000). Adult wing margins were measured from digital images for comparing congeners following the protocol of Bálint et al. (2000). The measurements are given in Table 2. One male and one female Pseudolucia specimen have been dissected in the Hungarian Natural History Museum (Bálint genitalia preparation number 1618 for male DBC-302 and 1619 for female DBC-301), digitized and compared with congeners. Samples were also secured for molecular studies.

Molecular analyses have been carried out in the laboratory lead by Roger Vila (specimens examined are documented as RVcoll16M\#\#\#; see above). Legs were taken from all individuals available of "torotorensis" and the mitochondrial marker cytochrome c oxidase subunit I (COI) was sequenced. The method used is described in detail by Talavera et al. (2013) and by Vodă et al. (2015). Also, a number of outgroup taxa within Pseudolucia were sequenced using the same protocol, as well as sequences available in GenBank for the $2172 \mathrm{bp}$ fragment spanning markers $\mathrm{COI}+$ leu-tRNA + COII (Table 1). PCR products were purified and sequenced by Macrogen Inc. Sequences were edited and aligned using GENEIOUS PRO 6.0 .5 created by Biomatters (http://www.geneious.com/). All new sequences have been deposited in GenBank (for accession numbers see Table 1). A Neighbour-Joining phylogenetic tree was obtained using a HKY distance model in GENEIOUS PRO 6.0.5, with 100 bootstrap pseudo-replicates to assess the robustness of the tree clades.

\section{RESULTS AND DISCUSSION}

\section{Identification}

(Figures 1-11)

The species collected in Bolivia belongs to the chilensis species group of Pseudolucia Nabokov, 1945 (type species: Lycaena collina Philippi, 1859 ) because the dorsal wing surfaces of both sexes have no structural colouration, the ventral hindwing pattern has no conspicuous median pat- 
Table 1. Samples used in this study with the specimen codes, original localities and GenBank accession numbers.

\begin{tabular}{|c|c|c|c|c|c|c|c|}
\hline Code & Species & Date & Locality & Country & $\begin{array}{l}\text { Altitude } \\
\text { (m.a.s.l.) }\end{array}$ & Collector & $\begin{array}{l}\text { GenBank } \\
\text { Acc. Num. }\end{array}$ \\
\hline BD02B788 & $\begin{array}{l}\text { Pseudolucia } \\
\text { barrigai }\end{array}$ & $2001-12-25$ & $\begin{array}{l}\text { Valle de las Leñas, } \\
\text { Mendoza }\end{array}$ & Argentina & 2310 & D. Benyamini & GQ128995 \\
\hline BD02B792 & $\begin{array}{l}\text { Pseudolucia } \\
\text { shapiroi }\end{array}$ & $2001-12-26$ & $\begin{array}{l}\text { Valle de las Leñas, } \\
\text { Mendoza }\end{array}$ & Argentina & 2068 & D. Benyamini & GQ129005 \\
\hline BD02B796 & $\begin{array}{l}\text { Pseudolucia } \\
\text { collina }\end{array}$ & $2001-12-27$ & $\begin{array}{l}\text { Lago Alumine, } \\
\text { Neuquén }\end{array}$ & Argentina & 1233 & D. Benyamini & GQ129000 \\
\hline BD02B797 & $\begin{array}{l}\text { Pseudolucia } \\
\text { grata }\end{array}$ & $2001-12-27$ & $\begin{array}{l}\text { Lago Alumine, } \\
\text { Neuquén }\end{array}$ & Argentina & 1233 & D. Benyamini & GQ129001 \\
\hline BD02B801 & $\begin{array}{l}\text { Pseudolucia } \\
\text { tamara }\end{array}$ & $2001-12-28$ & $\begin{array}{l}\text { Río Trafal, } 1 \text { km NW } \\
\text { Confluencia, Neuquén }\end{array}$ & Argentina & 861 & D. Benyamini & GQ129007 \\
\hline BD02B807 & $\begin{array}{l}\text { Pseudolucia } \\
\text { patago }\end{array}$ & $2001-12-30$ & Chile Chico, Aisén & Chile & 240 & D. Benyamini & GQ129004 \\
\hline BD02B812 & $\begin{array}{l}\text { Pseudolucia } \\
\text { vera }\end{array}$ & 2002-01-04 & $\begin{array}{l}\text { Volcán Villarica, } \\
\text { Temuco, Araucania }\end{array}$ & Chile & 1432 & D. Benyamini & GQ129008 \\
\hline BD02B813 & $\begin{array}{l}\text { Pseudolucia } \\
\text { charlotte }\end{array}$ & 2002-01-04 & Temuco, Araucania & Chile & & D. Benyamini & GQ128998 \\
\hline MFB00N227 & $\begin{array}{l}\text { Pseudolucia } \\
\text { chilensis }\end{array}$ & $2000-12-01$ & $\begin{array}{l}\text { Farellones, Santiago } \\
\text { Metropolitan }\end{array}$ & Chile & 1850 & M.F. Braby & GQ128999 \\
\hline OM05G417 & $\begin{array}{l}\text { Pseudolucia } \\
\text { parana }\end{array}$ & 2004-03-02 & Vila Velha, Parana & Brazil & & O. Mielke & GQ129003 \\
\hline RV03V020 & $\begin{array}{l}\text { Pseudolucia } \\
\text { asafi }\end{array}$ & 2003-01-21 & $\begin{array}{l}\text { Céspedes, Illapel, } \\
\text { Coquimbo }\end{array}$ & Chile & 2650 & R. Vila & GQ128997 \\
\hline RV03V073 & $\begin{array}{l}\text { Pseudolucia } \\
\text { henyah }\end{array}$ & $2003-01-26$ & $\begin{array}{l}\text { Crtr.5 Km338, Fray } \\
\text { Jorge, Coquimbo }\end{array}$ & Chile & & R. Vila & GQ129002 \\
\hline RV03V101 & $\begin{array}{l}\text { Pseudolucia } \\
\text { annamaria }\end{array}$ & $01-28$ & Alcohy & Chile & 2000 & R. Vila & GQ128996 \\
\hline RV03V112 & $\begin{array}{l}\text { Pseudolucia } \\
\text { sibylla }\end{array}$ & 2003-01-29 & $\begin{array}{l}\text { Río La Laguna, Paso } \\
\text { del Agua Negra, } \\
\text { Coquimbo }\end{array}$ & Chile & 3700 & R. Vila & GQ129006 \\
\hline RVcoll11J799 & $\begin{array}{l}\text { Pseudolucia } \\
\text { oligocyanea }\end{array}$ & 2011-10-20 & $\begin{array}{l}22 \mathrm{~km} \text { South Socaire, } \\
\text { Antofagasta, Atacama }\end{array}$ & Chile & 3650 & D. Benyamini & MG783988 \\
\hline RVcoll12R451 & $\begin{array}{l}\text { Pseudolucia } \\
\text { balinti }\end{array}$ & 2011-07-09 & $\begin{array}{l}\text { Sierra del Tontal, } \\
\text { Calingasta, San Juan }\end{array}$ & Argentina & 3238 & D. Benyamini & MG783986 \\
\hline RVcoll12R545 & $\begin{array}{l}\text { Pseudolucia } \\
\text { aureliana }\end{array}$ & 2012-12-09 & $\begin{array}{l}\text { ca. } 10 \text { km S. Inca de } \\
\text { Oro, Copiapó, } \\
\text { Atacama }\end{array}$ & Chile & 2000 & D. Benyamini & MG783985 \\
\hline RVcoll12R547 & $\begin{array}{l}\text { Pseudolucia } \\
\text { patago }\end{array}$ & $2012-12-13$ & $\begin{array}{l}\text { Río Jeinimeni, Chile } \\
\text { Chico, Aisén }\end{array}$ & Chile & 240 & D. Benyamini & MG783989 \\
\hline RVcoll12R549 & $\begin{array}{l}\text { Pseudolucia } \\
\text { maricunga }\end{array}$ & 2012-12-11 & $\begin{array}{l}\text { Cuesta Codoceo, } \\
\text { Copiacó, Atacama }\end{array}$ & Chile & 3933 & D. Benyamini & MG783987 \\
\hline RVcoll16M146 & $\begin{array}{l}\text { Pseudolucia } \\
\text { "torotorensis" }\end{array}$ & 2016-03-30 & $\begin{array}{l}\text { Torotoro National } \\
\text { park, Potosí }\end{array}$ & Bolivia & $\begin{array}{l}2700- \\
2850\end{array}$ & G. Siebel & MG783990 \\
\hline RVcoll16M147 & $\begin{array}{l}\text { Pseudolucia } \\
\text { "torotorensis" }\end{array}$ & 2016-03-30 & $\begin{array}{l}\text { Torotoro National } \\
\text { park, Potosí }\end{array}$ & Bolivia & $\begin{array}{l}2700- \\
2850\end{array}$ & G. Siebel & MG783991 \\
\hline RVcoll16M148 & $\begin{array}{l}\text { Pseudolucia } \\
\text { "torotorensis" }\end{array}$ & $2016-12-13$ & $\begin{array}{l}\text { Torotoro National } \\
\text { park, Potosí }\end{array}$ & Bolivia & $\begin{array}{l}2700- \\
2850\end{array}$ & J.F.G Serrudo & MG783992 \\
\hline RVcoll16M149 & $\begin{array}{l}\text { Pseudolucia } \\
\text { "torotorensis" }\end{array}$ & $2016-12-13$ & $\begin{array}{l}\text { Torotoro National } \\
\text { park, Potosí }\end{array}$ & Bolivia & $\begin{array}{l}2700- \\
2850\end{array}$ & J.F.G Serrudo & MG783993 \\
\hline RVcoll16M150 & $\begin{array}{l}\text { Pseudolucia } \\
\text { "torotorensis" }\end{array}$ & 2016-12-13 & $\begin{array}{l}\text { Torotoro National } \\
\text { park, Potosí }\end{array}$ & Bolivia & $\begin{array}{l}2700- \\
2850\end{array}$ & J.F.G Serrudo & MG783994 \\
\hline
\end{tabular}




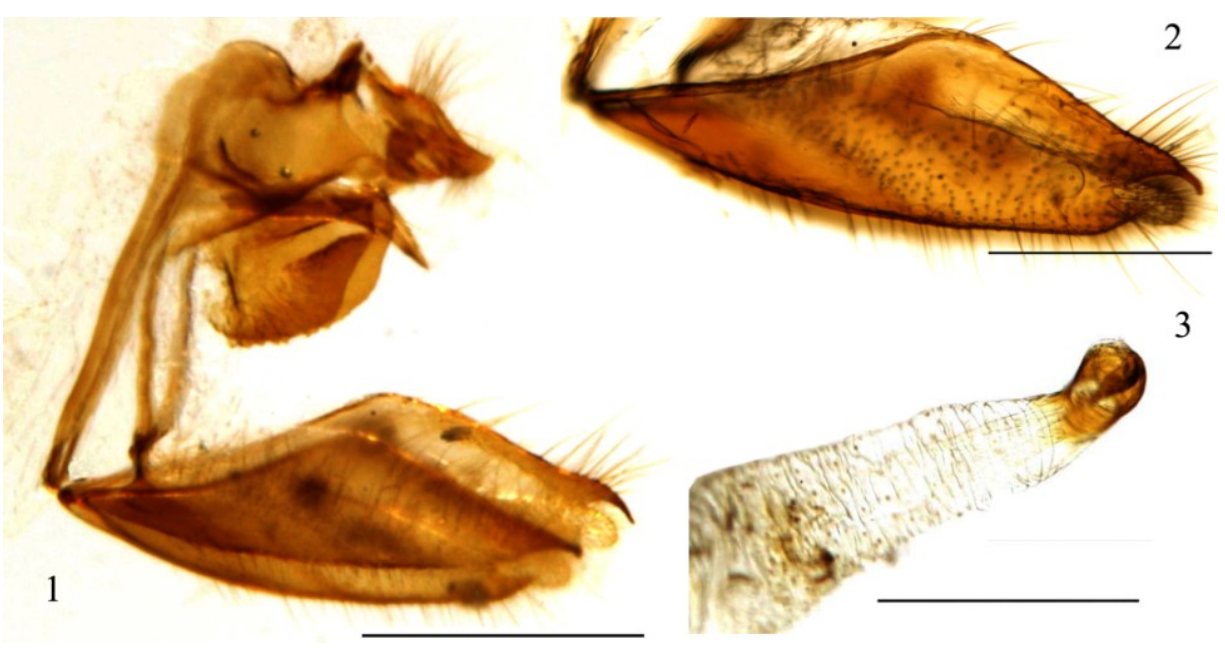

Figures 1-3. Genitalia of the Bolivian Pseudolucia specimens "torotorensis". 1 = male, the whole organ in lateral view; $2=$ male genitalia valva, in larger magnification; 3 = female genitalia ductus with sclerotized henia in dorsal view (scale bars $=0,8 \mathrm{~mm}$ ) (photos: Hungarian Natural History Museum).

pattern (Figs. 1-8), male genitalia tegumen has a dorso-lateral projection, uncus lobe shape is securiform, aedeagus suprazonal portion is extremely short and pointed, the apex is pointed and the female genitalia ductus is heavily pleated (Figs. $1-3)$.

The following characters examined in the male and female "torotorensis" adults differ from $P$. chilensis and match well with the only known holotype specimen of Pseudolucia jujuyensis: (1) wing surfaces without orange scaling $(P$. chilensis with orange scaling), (2) hindwing ventral wing surface maculation without black scaling $(P$. chilensis with black scaling), and (3) male genitalia valva with angulated costa $(P$. chilensis costa non-angulated). These three observations suggest that the Bolivian "torotorensis" specimens are morphologically close to the holotype of $P$. jujuyensis (Figs. 4-11).

The traits of the "torotorensis" specimens that differ compared with $P$. jujuyensis holotype are the followings: (1) the ground colour and macu- lation seem to be lighter and (2) male genitalia valva is slightly shorter. We do not have enough material for analysing the variability of these traits, but it is known that the first trait could be strongly influenced by temperature, as experiments carried on Polyommatus icarus (Rottemburg, 1775) have demonstrated (Kertész et al. 2016). The most striking character of the $P$. jujuyensis holotype in comparison with $P$. chilensis was the peculiar wing shape typified by the wing margin mean ratios 1.54/1.09 (see Bálint et al. 2000). Given the similarity to the ratios of the Bolivian specimens, 1.37/1.06, 1.53/1.07, 1.50/ 1.12 and 1.33/1.11 ( $c f$. Table 2), this character seems not to support a species distinction at the moment, although we do not know the variability of the Jujuy population.

Summarizing all of these results, we can propose two alternative hypotheses: (1) the holotype of $P$. jujuyensis represents the same species observed on Torotoro, but it is an extreme individual collected at the very southern edge of the species' range, or (2) the holotype of $P$. jujuyensis 


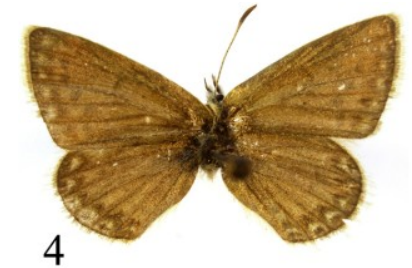

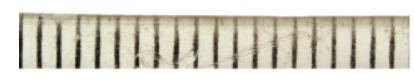
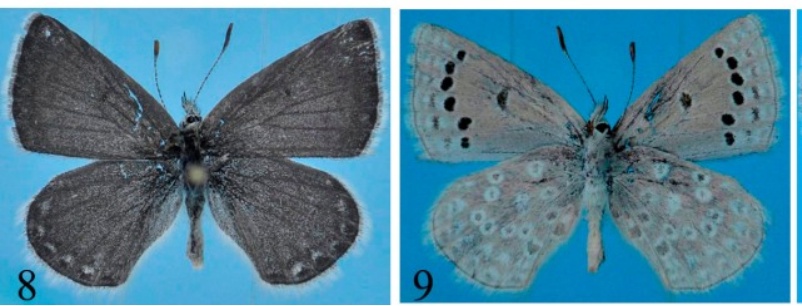
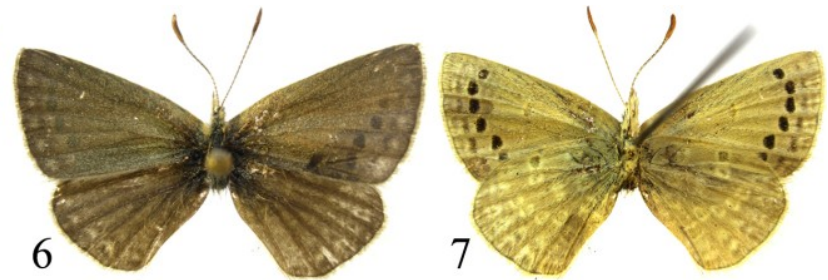

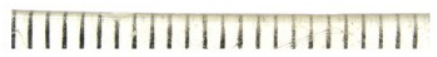
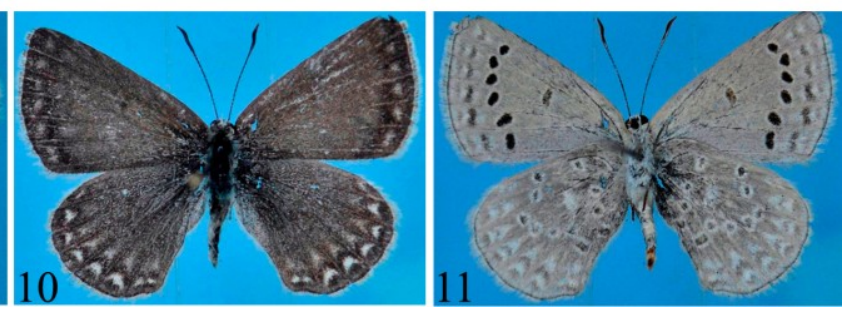

Figures 4-7. Male Pseudolucia museum specimens documented under identical light conditions. 4-5: the holotype of Pseudolucia jujuyensis, $4=$ in dorsal view, and 5 = in ventral view; 6-7: the HNHM specimen of "torotorensis", $3=$ in dorsal and 4 = in ventral view. (Scale bars $1 \mathrm{~mm}$ ) (photos: Katona Gergely).

Figures 8-11. Imagines of the Bolivian Pseudolucia specimens "torotorensis", collected in Potosí, Torotoro National park, 2700-2850 m, 13.XII.2016 by J. F. G. Serrudo. $8=$ male (DBC-0302) in dorsal view; 9 = ditto, in ventral view; $10=$ female $(\mathrm{DBC}-0301)$ in dorsal view; $11=$ ditto, in ventral view (forewing costa length $13 \mathrm{~mm}$ for Figs. 8-9, and $12 \mathrm{~mm}$ for Figs. 10-11) (photos: Ofír Tomer).

Table 2. Forewing length measurements of Pseudolucia "torotorensis" individuals.

\begin{tabular}{|c|c|c|c|c|}
\hline $\begin{array}{c}\text { Catalog } \\
\text { reference }\end{array}$ & Sex & Costal margin (A) & Outer margin (B) & Anal margin (C) \\
\hline DBC-0300 & M & $11 \mathrm{~mm}$ & $8 \mathrm{~mm}$ & $8.5 \mathrm{~mm}$ \\
\hline DBC-0301 & $\mathrm{F}$ & $13 \mathrm{~mm}$ & $9.5 \mathrm{~mm}$ & $10 \mathrm{~mm}$ \\
\hline DBC-0302 & $\mathrm{M}$ & $12 \mathrm{~mm}$ & $8 \mathrm{~mm}$ & $9 \mathrm{~mm}$ \\
\hline DBC-0303 & $\mathrm{M}$ & $12 \mathrm{~mm}$ & $9 \mathrm{~mm}$ & $10 \mathrm{~mm}$ \\
\hline $\begin{array}{c}\text { HNHM } \\
\text { specimen }\end{array}$ & $\mathrm{M}$ & $11 \mathrm{~mm}$ & $7.5 \mathrm{~mm}$ & $8 \mathrm{~mm}$ \\
\hline
\end{tabular}

is a typical individual and the populations of Coroya and Torotoro are specifically distinct. At this moment the material in our disposal is not enough to take a decision hence we provisionally regard the two populations as conspecific. For a final decision regarding their taxonomy the species $P$. jujuyensis has to be rediscovered and new samples analysed.

\section{Molecular analysis}

(Figure 12)

The molecular analysis of the genus using mitochondrial DNA shows that "torotorensis" belongs to the chilensis-group and forms a wellsupported clade together with $P$. chilensis and $P$. 


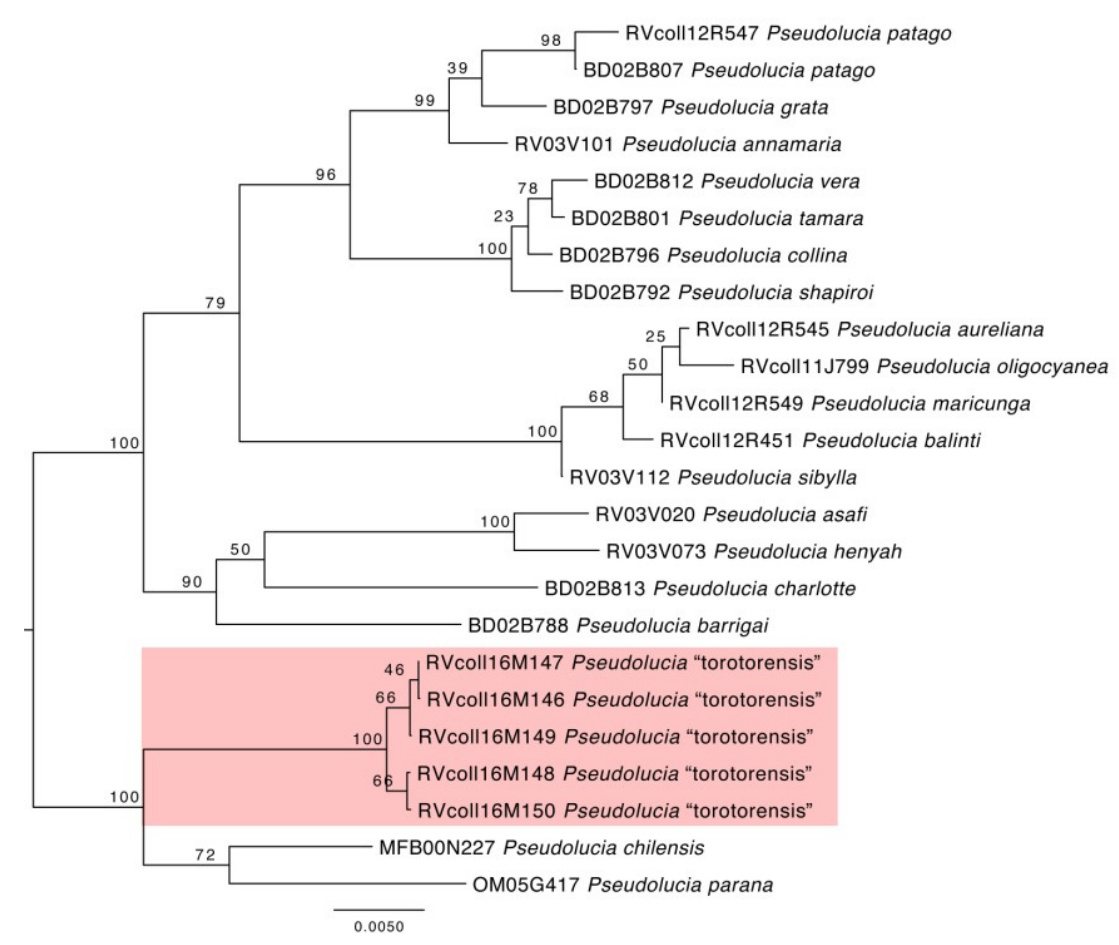

Figure 12. Neighbour-Joining tree for Pseudolucia based on mitochondrial sequences $C O I+l e u-t R N A+C O I I$ with bootstrap values $>50$ indicated. Scale units are presented in substitutions per site. The Pseudolucia samples from Bolivia are highlighted.

parana. All five "torotorensis" specimens form a highly supported clade with little variability (a single substitution in $C O I$ shared by to specimens) that is sister to the clade including $P$. chilensis and $P$. parana. Specimens of "torotorensis" display uncorrected p-distances to the two sister species of between 2.1 and $3.2 \%$ for the $C O I$, which translates to between 1 and 2 million years of isolation assuming a mitochondrial standard substitution rate ranging from $1.5 \%$ to $2.3 \%$ uncorrected pairwise distance per million years (cf. Brower 1994). Thus, "torotorensis" split before P. parana became isolated in the Atlantic region of Brazil, which happened approximately 1 million of years ago (divergences between $P$. chilensis and $P$. parana range between 1.7 and $2.0 \%$ for the $C O I$ ).

We cannot know where $P$. jujuyensis and $P$. sosneada would fall in the phylogenetic tree, as the samples taken from the type material did not yield any results. But on the ground of morphology we suppose that $P$. jujuyensis is in sister relationship with "torotorensis", as appears to be the same in regards to P. chilensis and P. sosneada.

\section{Distribution and zoogeography}

(Figures 13-14)

According to known distribution ranges of other Pseudolucia species an almost $800 \mathrm{~km}$ of latitudinal distance between the type locality of $P$. jujuyensis and the collecting site in Torotoro may indicate two distinct taxa. However, in $27^{\text {th }}$ of December, 2016 the first author observed a Pseudolucia species in a locality $60 \mathrm{~km}$ north of the Argentine border which is about $400 \mathrm{~km}$ south of Torotoro (Fig. 13). This new location is in the vicinity of the Argentine town Tarija (approximate coordinates: $21^{\circ} 28^{\prime} 33^{\prime \prime} \mathrm{S} 64^{\circ} 48^{\prime} 17^{\prime \prime} \mathrm{W}$ ) and is in halfway between Coraya (the type locality of $P$. jujuyensis) and Torotoro. Material or documentation of this putative population is still not available, but it was remarked that the observed specimen is similar to the species recorded in the vicinity of Torotoro.

However, knowing that $P$. chilensis has a similarly extended range along the Pacific coast of 


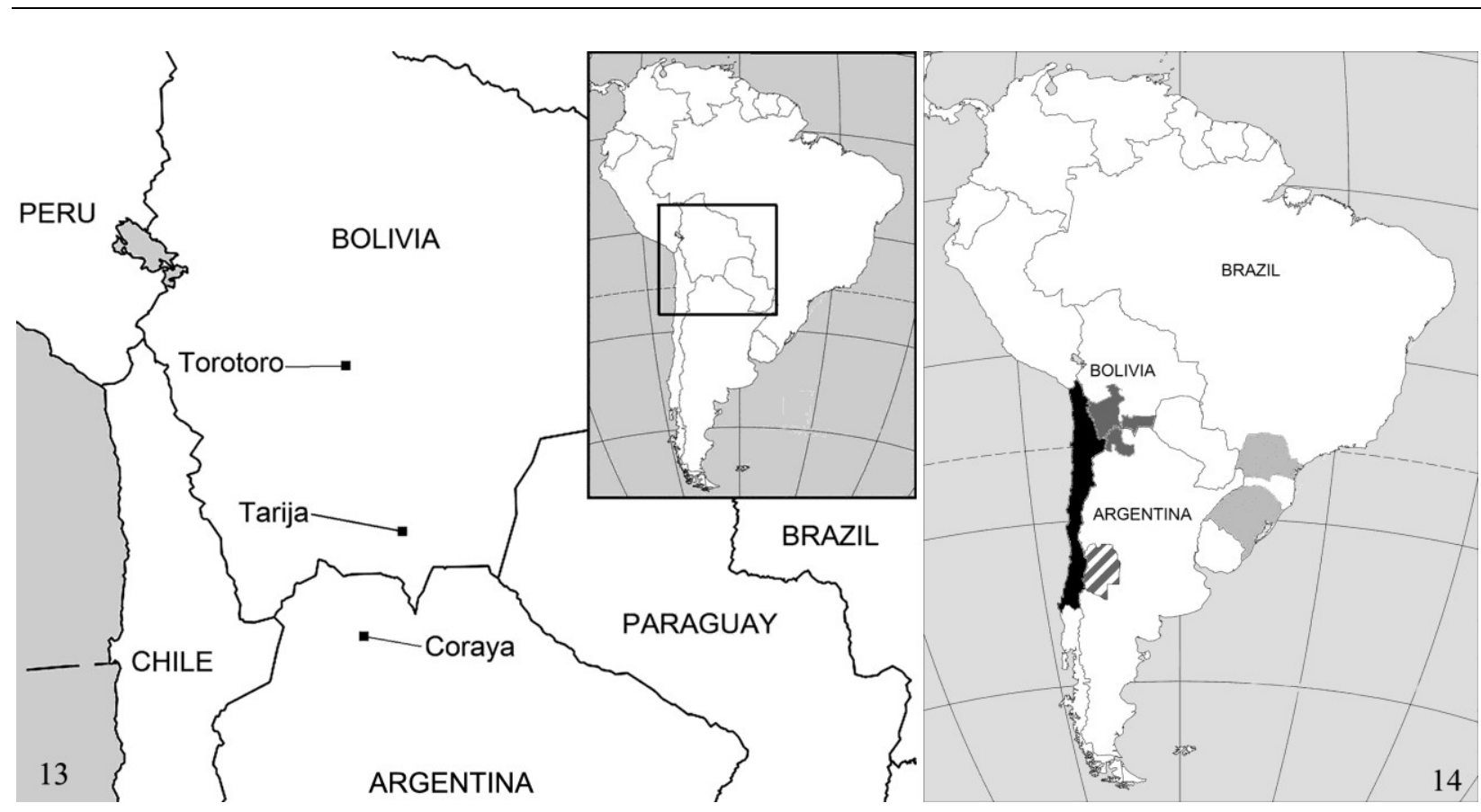

Figure 13. Geographical locations of the two known occurrences of Pseudolucia in Bolivia (Torotoro, department Potosí and Tarija, department Tarija), and the most northern known occurrence of Pseudolucia in Argentina (Coraya, deparment of Jujuy, the type locality of Ps. jujuyensis).

Figure 14. The general distribution of the chilensis species group of Pseudolucia indicated by administrative regions of various countries. Light grey highlighted states in Brazil: P. parana; dark grey highlighted regions in Bolivia: "torotorensis" dark grey highlighted province in Argentina: P. jujuyensis; striped province in Argentina P. sosneada, and black highlighted regions in Chile: P. chilensis.

Chile, it cannot be excluded that $P$. jujuyensis possesses a similarly wide Eastern Andean distribution ( $c f$. Bálint, Johnson \& Eisele 2000) from the Torotoro region in Bolivia in the north to Jujuy province in Argentina in the south. The phenomenon that the ranges of hypothetical sister species inhabiting the Eastern and Western sides of the Andes are latitudinally shifted is well documented (see Shapiro 1991 and Benyamini 2013). Probably this phenomenon is observed here in the case of the $P$. chilensis and $P$. jujuyensis species pair (cf. Fig. 14).

\section{Biology}

\section{(Figures 15-18)}

All individuals were observed in the close vicinity of Cuscuta globiflora Engelmann, 1859, the presumed larval host plant. Indeed, all the members of the chilensis-group apparently specialize on Cuscuta.
The genus Cuscuta is parasitic on other plants, and it is widely distributed in the Potosí region causing considerable harms for Bolivian farmers (Figs. 15-16). Males are flying near the larval host plant waiting for females, and hilltop and display territorial behaviour along upper edges of slopes and ridges (Fig. 17). In the locality just 1 $\mathrm{km}$ out of the Torotoro village, where the species was recorded first, one male individual was fighting with Strymon oribata males patrolling the same ridge (Fig. 18).

The females fly around the presumed larval host plant and crawl deep possibly for laying eggs. The caterpillars supposedly feed on buds, flowers and fruits of Cuscuta, as do the closely related species in other regions. According to regional weather data, we believe that the species may have at least three annual generations and that the fully-grown larvae of the last brood diapause until the next spring (NovemberDecember). 


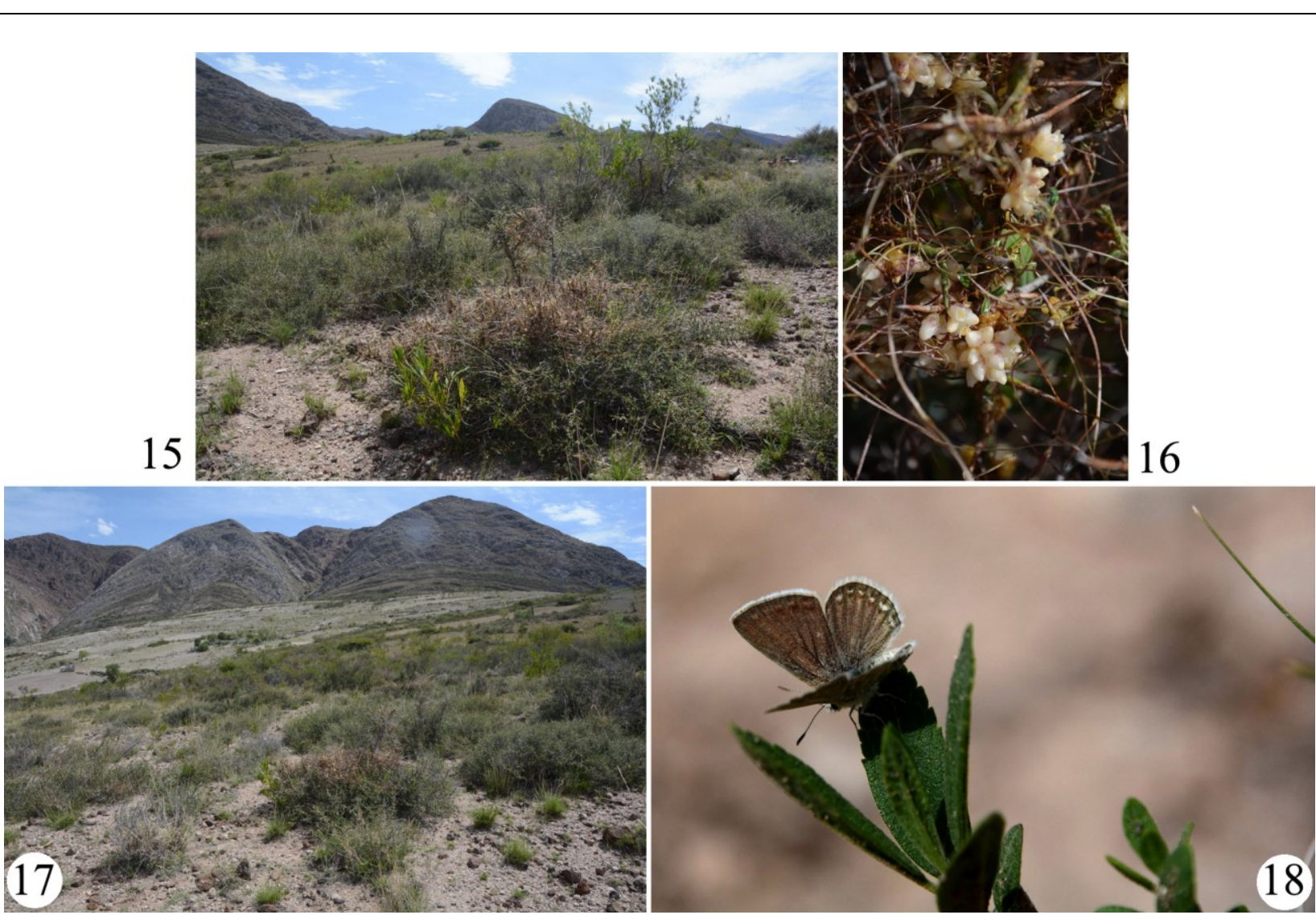

Figure 15. The site where the first Pseudolucia individual has been recorded in Bolivia, $500 \mathrm{~m}$ south of Torotoro village $(-18.141860 \mathrm{~S},-65.760080 \mathrm{~W})$; in front there is a shrub covered by Cuscuta globiflora (photo: D. Benyamini).

Figure 16. Cuscuta globiflora in the vicinity of Torotoro, Bolivia, developing buds and flowers, the diet of Pseudolucia caterpillars (photo: D. Benyamini).

Figure 17. The site where female and male Pseudolucia individuals occurred together, $1 \mathrm{~km}$ south of Torotoro village, $c a .2800$ $\mathrm{m}$; males were hilltopping and patrolling along the ridge edges with Strymon oribata males (photo: D. Benyamini).

Figure 18. Territorial male Pseudolucia "torotorensis" at the edge of a ridge, in the vicinity of Torotoro village, Bolivia (photo: D. Benyamini).

\section{Closing remarks}

The region of Torotoro is well known because of the finding of spectacular footprints of five different species of dinosaurs, but its Lepidoptera fauna is poorly explored. Nevertheless, the occurrence of Pseudolucia in Torotoro agrees with the existence of a peculiar biome in Bolivia, which also extends south to the northern provinces of Argentina, known as "prepuna" (Cabrera 2000; López 2000).

It seems that this biome, although poor in biodiversity compared to other Neotropical sites, has a Lycaenidae fauna mainly composed by species endemic for the region such as Madeleinea lea Benyamini, Bálint \& Johnson, 1995; Rhamma lapazensis (K. Johnson, 1992), Strymon oribata (Weymer, 1890) and Thecloxurina cillutincare (Draudt, 1919). Another example of lycaenid endemic to the prepuna ecoregion is an undescribed Rhamma (recorded as Strymon heodes by Serrudo 2013), which probably belongs to the chilensis mimicry ring (Benyamini 1995).

Further investigations are needed for mapping the boundaries and complexity of the butterfly fauna in this rarely explored part of the Neotropical region. 
Acknowledgements - Genetic analyses were supported by projects CGL2016-76322-P (AEI/FEDER, UE) and 2014SGR-1532 (Generalitat de Catalunya); Cecília Corbella helped in the laboratory. Professor Uzi Plitmann (The Hebrew University, Jerusalem), identified the Cuscuta species. Gergely Katona (Budapest, HNHM) and Ofír Tomer (Bet-Arye, Israel) helped in the preparation of the figures. Zsolt Bálint was supported by the scientific OTKA programs K 111741 and K 115724.

\section{REFERENCES}

BÁlint, Zs. \& BENYAMINI, D. (2013): Pseudolucia maricunga sp. n., a new high Andean butterfly from northern Chile (Lepidoptera, Lycaenidae, Polyommatinae). Folia entomologica hungarica, 74: 175-183.

BÁLINT, Zs. \& BENYAMINI, D. (2017): Corrected synonymies: the identities of Strymon bicolor (Philippi, 1859) and Strymon heodes (Drucem, 1919). Opuscula Zoologica Budapest, 48: 61-69. doi: 10.18348/opzool.2017.1.61

BÁlint, Zs., JOHnSON, K. \& EISELE, R. (2000): Description of the sister species of Pseudolucia chilensis (Blanchard, 1852) (Lepidoptera: Lycaenidae). Folia entomologica hungarica, 61: 169-179.

BENYAMINI, D. (1995): Synopsis of biological studies of the Chilean Polyommatini (Lepidoptera: Lycaenidae). Reports of the Museum of Natural History, University of Wisconsin (Stevens Point), 52: 1-51.

BenYAminI, D. (2013): Pseudolucia balinti sp. n. of the plumbea-sibylla species group in Central-West Argentina (Lepidoptera: Lycaenidae: Polyommatinae). Folia entomologica hungarica, 74: 157-174.

BENYAMINI, D. \& BÁlint, Zs. (2015): Descriptions of eight new Pseudolucia species from Argentina with an updated list of species distributed in the australregions of South America (Lepidoptera, Lycaenidae: Polyommatinae). Folia entomologica hungarica, 76: 173-216.
BROWER, A.V.Z. (1994): Rapid morphological radiation and convergence among races of the butterfly Heliconius erato inferred from patterns of mitochondrial-DNA evolution. Proceedings of the National Academy of Sciences USA, 91: 64916495. doi: 10.1073/pnas.91.14.6491

CABRERA, A.L. (1976): Regiones fitogeográficas argentinas. Enciclopedia Argentina de Agricultura y Jardinería, Tomo II Fs. 1. Ed. ACME. Bs. As. Argentina, $85 \mathrm{pp}$.

Kertész, K., Piszter, G., HorvÁth, Zs. E., BÁlint, ZS. \& BIRÓ, L.P. (2017): Changes in structural and pigmentary colours in response to cold stress in Polyommatus icarus butterflies. Scientific Reports, 17(7): 1118. doi: 10.1038/s41598-017-01273-7

LÓPEZ, R.P. (2000): La prepuna boliviana. Ecología en Bolivia, 34: 45-70.

NABOKOV, V. (1945): Notes on Neotropical Plebejinae. Psyche, 52: 1-61.

SHAPIRO, A. (1991): The zoogeography and systematics of the Argentina Andean and Patagonian pierid fauna. Journal of Research on the Lepidoptera, 28(3): 137-238, 4 pls, 24 figs, 4 tabs.

Talavera, G., Lukhtanov, V.A., Pierce, N.E. \& VILA, R. (2013): Establishing criteria for higherlevel classification using molecular data: the systematics of Polyommatus blue butterflies (Lepidoptera, Lycaenidae). Cladistics, 29: 166-192. doi: $10.1111 / \mathrm{j} .1096-0031.2012 .00421 . \mathrm{x}$

VODĂ, R., DAPPORTO, L., DINCĂ, V. \& VILA, R. (2015): Why Do Cryptic Species Tend Not to CoOccur? A case study on two cryptic pairs of butterflies. PLoS One, 10(2): e0117802. doi: 10.1371 /journal. pone. 0117802

WINTER, W.D. Jr. (2000): Basic techniques for observing and studying butterflies \& moths. The Lepidopterists' Society Memoir Number 5. Lepidopterists' Society, Los Angeles, xviii + 444 pp. 